\title{
GEOMORPHOLOGICAL DYNAMICS OF THE ELEVATED GEOSYSTEMS OF THE BORBOREMA HIGHLANDS, NORTHEAST OF BRAZIL, FROM OPTICALLY STIMULATED LUMINESCENCE DATING OF HILLSLOPE SEDIMENTS
}

\author{
DINÂMICA GEOMORFOLÓGICA DOS GEOSSISTEMAS ELEVADOS DO PLANALTO \\ DA BORBOREMA, NORDESTE DO BRASIL, A PARTIR DA DATAÇÃO POR \\ LUMINESCENCIA OPTICAMENTE ESTIMULADA DE SEDIMENTOS DE \\ ENCOSTAS
}
DYNAMIQUE GÉOMORPHOLOGIQUE DES GÉOSYSTÈMES ÉLEVÉS DES HAUTES TERRES DE LA BORBOREMA, AU NORD-EST DU BRÉSIL, À PARTIR DE LA DATATION POUR LUMINESCENCE OPTIQUEMENT STIMULÉE DE SÉDIMENTS DE VERSANTS

\section{ANTONIO CARLOS DE BARROS CORREAA ${ }^{1}$ KLEYTHON DE ARAUJO MONTEIRO²}

${ }^{1}$ Associate Professor, Department of Geographical Sciences Federal University of Pernambuco. E-mail: $\underline{\text { dbiase2001@ @erra.com.br. }}$

\author{
${ }^{2}$ Adjunct Professor, IGDEMA
}

Federal University of Alagoas

\begin{abstract}
The geomorphological dynamics of the elevated compartments of the Borborema Highlands, northeastern Brazil, were assessed through the analysis of hillslope sediments. The chosen study area was the Baixa Verde massif, in the State of Pernambuco. The main morphostratigraphic features were identified on the basis of their relevance to the reconstruction of the geomorphological dynamics. First hillslope deposits in the shape of colluvial fans, or infills of hollows and zero order catchments were identified. Following field study of the stratigraphic interactions in four sampling areas within the massif, samples were collected for a number of laboratory tests: sedimentological analysis, soil micromorphology and Optically Stimulated Luminescence (OSL) dating. A fragment of charcoal found on the top of a gravel layer was radiocarbon- dated. The sampling procedures were aimed at the characterization of the several depositional units. The results of the dating of 14 sampling sites point to the occurrence of discrete events of hillslope material remobilization within the last 20,000 years as a dynamic response of the geomorphological systems to the following events: the Last Glacial Maximum (LGM), the Pleistocene/Holocene transition, the mid-Holocene climatic optimum and the recent anthropic period and its short term climatic oscillations.
\end{abstract}

Keywords: hillslope sediments. Borborema Highlands. Luminescence dating. Paleoclimates.

\section{RESUMO}

A dinâmica geomorfológica dos compartimentos elevados do Planalto da Borborema, Nordeste do Brasil, foi avaliada por meio da análise de sedimentos de encostas. A área de estudo escolhida foi o maciço da Baixa Verde, no Estado de Pernambuco. As principais feições morfoestratigráficas foram identificadas com base na sua relevância para a reconstrução da dinâmica geomorfológica. Foram identificados os primeiros depósitos de encosta em forma de leques coluviais, ou preenchimentos de depressoes e bacias hidrográficas de ordem zero foram identificadas. Após o estudo de campo das interações estratigráficas em quatro áreas de amostragem dentro do maciço, amostras foram coletadas para uma série de testes de laboratório: análise sedimentológica, micromorfologia do solo e datação por Luminescência Opticamente Estimulada (LOS). Um fragmento de carvão encontrado no topo de uma camada de cascalho foi datado por radiocarbono. Os procedimentos de amostragem visaram à caracterização das diversas unidades deposicionais. Os resultados da datação de 14 pontos de amostragem apontam para a ocorrência de eventos discretos de remobilização de material de encosta nos últimos 20.000 anos como uma resposta dinâmica dos sistemas geomorfológicos aos seguintes eventos: Último Máximo Glacial (UMG), transição Pleistoceno / Holoceno, o ótimo climático do Holoceno médio e o período antrópico recente e suas oscilações climáticas de curto prazo.

Palavras-chave: Sedimentos de encostas. Planalto da Borborema . Datação por luminescência. Paleoclimas. 


\section{RÉSUMÉ}

La dynamique géomorphologique des compartiments élevés des hauts plateaux de la Borborema, au Nord-est du Brésil, a été évaluée par l'analyse des sédiments des pentes. La zone d'étude choisie était le massif de la Baixa Verde, dans l'État de Pernambuco. Les principales caractéristiques morphostratigraphiques ont été identifiées sur la base de leur pertinence pour la reconstruction de la dynamique géomorphologique. Les premiers dépôts de versants en forme d'éventails colluviaux ou de remplissage de creux et de bassins versants d'ordre zéro ont été identifiés. Suite à l'étude sur le terrain des interactions stratigraphiques dans quatre zones d'échantillonnage du massif, des échantillons ont été prélevés pour un certain nombre de tests en laboratoire: analyse sédimentologique, micromorphologie du sol et datation par luminescence optiquement stimulée (LOS). Un fragment de charbon de bois trouvé au sommet d'une couche de gravier a été daté au radiocarbone. Les procédures d'échantillonnage visaient à caractériser les différentes unités de dépôt. Les résultats de la datation de 14 sites d'échantillonnage indiquent la survenue d'événements discrets de remobilisation des matériaux des versants au cours des 20000 dernières années en tant que réponse dynamique des systèmes géomorphologiques aux événements suivants: le dernier maximum glaciaire (DGM), le Pléistocène / Holocène transition, l'optimum climatique du milieu de l'Holocène et la période anthropique récente et ses oscillations climatiques à court terme.

Mots clés: sédiments des pentes. Borborema Highlands. Datation par luminescence. Paléoclimats.

\section{INTRODUÇÃO}

The spatio-temporal arrangement of contemporary geosystems results from their development, understood as a controlled transformation through the influence of local and regional parameters, both physical-natural and anthropogenic. During its evolution, elements and component flows of the geosystem face changes in their operational structure. For Danko et al. (2007) the development of a geosystem can be described as a set of cyclical changes, rhythmic oscillations and even regressive changes, which are expressed on the landscape's morphology, especially through the action of the conditioning factors such as climatic activities and neotectonics. In this way, the transformations of land use and occupation (anthropogenesis) come to be understood as modulators, especially of climatic action, on the morphological organizations of the landscape.

In the semiarid Northeast of Brazil, the impacts of anthropogenesis on surface coverings and even the creation of new accumulation landforms are recognized in the literature since the contributions of Crandall (1910) and James (1952). Monteiro (1988) typified the land use practices involved in land degradation in the elevated areas of the Borborema Highlands, giving rise to later works such as those by Corrêa (2011), Corrêa et al. (2016) and Azambuja and Corrêa (2020) focused on spatial delimitation, historical evolution and measurement of the process-response systems involved.

Nevertheless, these studies were limited to stablishing short term operation patterns of the geomorphic systems, as a consequence of the availability of assessment tools, mostly dependent on the direct observation (remote sensing and measurement of erosion by short halflife isotopes) of antecedent controlling elements (geometry of the source areas, climatic events, land use, textural characteristics of surface coverings) and geomorphic responses (erosion scars, formation of new depositional areas, local changes at the base level).

At this stage, it is important to emphasize which perspective among the current definitions of geosystem was used to conduct the experimental phase of this research. Thus, it is understood that a geosystem is a natural complex that presents a spatial (territorial) pattern resulting from its history, its functional autonomy and the role it plays in the context in which it is inserted. However, one must bear in mind that geosystems change over time (they are dynamic systems), as they have a history (temporality), which expresses itself as the dynamics of physical landscapes. Finally, it is necessary to reinforce that geosystems are hierarchical systems, since whilst they have functional autonomy (self-organization), they are inserted in a context of superior organization in which they perform a certain task. Therefore, the clarity of the adopted space-time scale of analysis is essential for an accurate assessment of the results obtained. 
The interactions between climate dynamics (fluctuations, changes, variability and rhythm) and the space-time responses of geosystems constitute a methodological and operational problem in physical geography. Thus, the study of physical-natural and anthropically induced transformations that result in new arrangements of geosystems seek to illuminate aspects of landscape functionality and morphology that otherwise are difficult to investigate by traditional descriptive methods, as it looks for the origin of landforms in its dynamics or resilience over time.

Adams et al. (1999) demonstrated that the main changes in energy input capable of reorganizing geomorphological systems throughout the Quaternary need to be considered on a logarithmic time scale, since the duration of the formative events varies from $10^{5}-$ interglacial/glacial cycles from the middle Pleistocene onwards - to $10^{1}$ recurrence intervals, in the case of events such as El Niño or the pendular oscillations of tropical Atlantic surface temperatures. Other events, such as the Daansgard-Oeschger cycles, display a periodicity of $10^{3}$ years, while others with little understood cyclicity can be treated as stochastic phenomena (Figure 1).

In all cases, landscape responses, in the form of accumulation and denudation landforms, present their own spatial hierarchy and residence time in the landscape, which reflect the connectivity rates between sediment production, transfer and release through the various components of the landscape. In the case of the semiarid Northeast of Brazil, these permanence and transfer timeframes are still poorly known and studied.

Figure 1 - An outline of the major climate events during the Quaternary in logarithmic timescale.

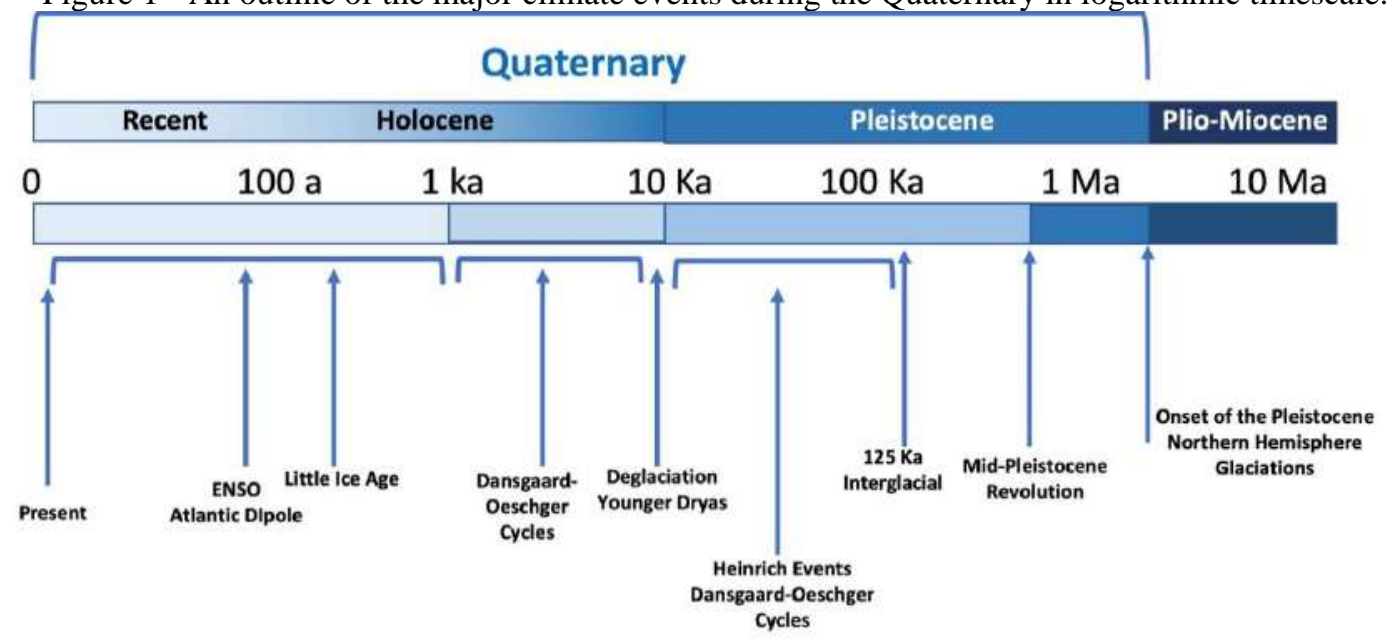

Source: adapted from Adams et al. (1999).

In this scenario, the main methodological and experimental questions emerge as one tries to establish the duration, morphological aspects, characteristics and properties of the surface coverings of the landscape, as well as defining the direction and intensity of environmental controls and variability acting upon them.

The geosystems considered to be of interest for this study rise above the general surface level of the Borborema Highlands (CORREA et al., 2019), in eastern northeast of Brazil, in the form of ridges and residual massifs. The area chosen for this case study was the Serra da Baixa Verde massif, State of Pernambuco, which constitutes one of the largest spaces of climaticecological exception embedded in the semi-arid core of the Northeast.

The singularity of the massif, rising from the semi-arid lowlands to form the largest continuous expanse to the regional summit surface $(1000-1100 \mathrm{~m}$ asl), with a local relief in 
excess of 700 meters, allowed the reconstruction of the geosystems temporality along a transect that encompasses the western escarpment of the Borborema Highlands (Figure 2). In this geomorphological context, landscape connectivity (sediment transfer among landform components) from the elevated surfaces to the surrounding pediments occurs mainly by means of lateral exchanges, between the slopes and the valley bottoms, and secondarily longitudinal transport, along the ephemeral stream channels.

Figure 2 - Location of the Baixa Verde massif and its hypsometry.

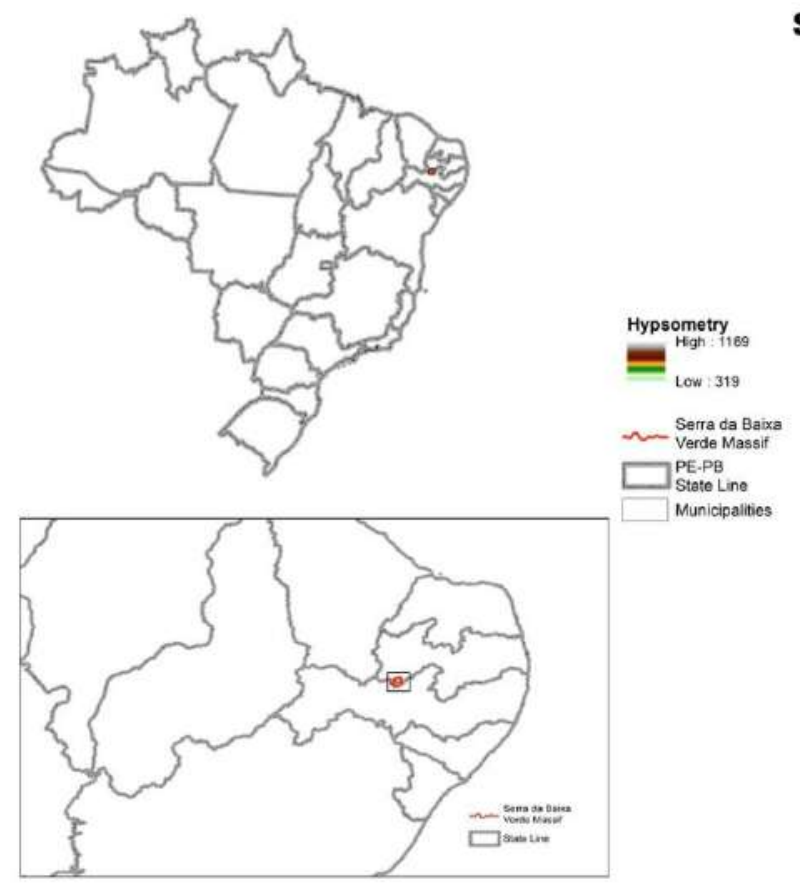

\section{SERRA DA BAIXA VERDE MASSIF HYPSOMETRY}

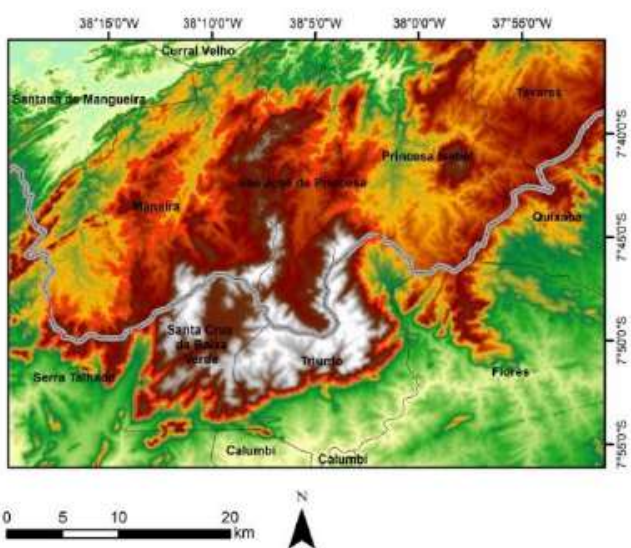

Source: the authors.

\section{LANDFORMS AND TIME IN THE NORTHEAST OF BRAZIL}

Despite amounting evidence of regional and local scale climatic mechanisms, operating within shorter timeframes, that ultimately led to landform development along the eastern seaboard of Brazil, for quite a long time landscape evolution was addressed, by a significant part of literature, solely by the interplay between long-term denudation and regional uplift as proposed by L. King in his pediplanation model (e.g., KING 1956, 1967). The rationale behind King's planation proposal has played a significant role in explaining both tectonics (or its absence) and long-term regional climate as driving mechanisms of morphogenesis in the Borborema Highlands - the most prominent plateau-like landform along the eastern façade of Brazil's Northeastern bulge.

As in other geographical contexts of the Brazilian passive and transforming continental margin quite a few interpretation problems have risen from the ap.lication of the classical planation surfaces ap.roach (PEULVAST; CLAUDINO-SALLES, 2004). Following King's model that associates landscape evolution to prevailing semi-arid conditions throughout most of the Cenozoic era, several studies proposed a direct link between semi-arid conditions and colluviation not only in the Northeast of Brazil, but also in the humid tropical contexts of the country's southeast region (BIGARELLA; MOUSINHO, 1965). These taken for granted semiarid conditions might have extended from the subtropical regions $\left(\sim 34^{\circ} \mathrm{S}\right)$ to the Equator. 
However, no conclusive empirical evidences of long lasting semi-arid episodes nor their correlative sediments have ever been shown (CORREA; MENDES, 2002). On top of that, the formation of thick regoliths and pervasive colluviation in the elevated topographic hollows of the Borborema highlands have been completely overlooked.

It follows that the refinement of late Quaternary landscape evolution in Northeastern Brazil and its spatial and temporal relationship with climate driven formative episodes require a more detailed ap.roach, focusing on unconsolidated surface coverings directly associated to landforms, and the mechanisms behind their deposition. Therefore, new methodological perspectives must be ap.lied in order to provide a more realistic account of the region's geomorphological history. This work proposes a shift on the spatial/temporal scales of ap.roach, from a regional perspective to a more detailed perspective. Thus, this work attempts to reconstruct the geomorphic evolution of a spatially contained landform encompassing the time lapse from the deposition of the oldest to the youngest colluvium found in the study area.

The assessment of the geomorphological dynamics of the Borborema Highlands focused on the Serra da Baixa Verde massif has prioritized the occurrence of datable surface deposits that were identified following a comprehensive field survey of the geomorphological features of the area. In that stage of the study, deposits that maintained a strong morphostratigraphic coherence were identified. Only deposits that showed a close relationship to the contemporary surface forms were considered in this analysis.

Among the several geomorphic features that were found in the field, hillslope deposits colluvium lato senso - shaped as topographic ramps or fans, either mantling convex wash surfaces or partially infilling the drainage axis of first order catchments, were chosen for sediment sampling. Therefore, in order to achieve the aims of the research a set of procedures was followed:

a) identification of hillslope/pediment sediment storage landforms within the Baixa Verde massif;

b) description of stratigraphic profiles and log-sections of the depositional landforms;

c) assessment of sedimentological properties of the sampled material;

d) establishment of an absolute chronology of depositional events based on OSL (Optically Stimulated Luminescence) dating of crystalline minerals (quartz and feldspar);

e) radiocarbon dating of charcoal fragments found amidst the sedimentary layers;

f) elaboration of qualitative models depicting the depositional events and their implications for the reconstruction of the late Quaternary paleogeographies of the area.

\section{METHODS}

The Serra da Baixa Verde massif is located in the northern center of the State of Pernambuco (Northeast of Brazil), $400 \mathrm{~km}$ to the west of the capital city, Recife. It consists of a topographically prominent Neoproterozoic syenite batholith that has cut through less resistant Neo- and Mesoproterozoic metamorphic complexes. The massif integrates the western escarpment of the Borborema Highlands. The area lies within the coordinates of $7^{\circ} 41^{\prime} \mathrm{S} / 7^{\circ}$ $54^{\prime} \mathrm{S}$ and $38^{\circ} 00^{\prime} \mathrm{W} / 38^{\circ} 11^{\prime} \mathrm{W}$, comprising a total surface area of ap.roximately $400 \mathrm{~km}^{2}$. The Serra da Baixa Verde massif forms the largest watershed divide between the States of Pernambuco and Paraíba, separating the drainage basins of the Piancó river, to the north, from the Pajeú river, to the south.

The study concentrated on the elevated hollows of the Serra da Baixa Verde massif, as well as along its southern escarpment. The hollows normally occur as first or zero order (unchanneled hollows) catchments. Such headwater features have been interpreted as areas of 
recurring, though infrequent, erosion and deposition of the sediments derived from the surrounding slopes (GRIEVE et al., 2018).

Using the Alos-PALSAR data, with a spatial resolution of $12.5 \mathrm{~m}$, a digital elevation model (DEM) of the area was elaborated in GeoTiff format. The image of the study area was processed in the software Arcgis 10.3, resulting in the delimitation of the massif and the drainage network, in addition to allowing the elaboration of the hypsometric and slope maps. The resulting products were used on the construction of the detailed geomorphological maps of the sampling areas.

The occurrence of colluvial infills and associated landforms was used as a guideline for the choice of sampling areas. Following the selection of the sampling areas, detailed geomorphological maps at were elaborated, in order to emphasize the morphoestratigraphic controls upon the deposits. The detailed geomorphological map.ing of the sampling areas followed the methodology of Demek (1972), which establishes the use of qualitative and quantitative measures of the landforms, emphasizing attributes observable at a local scale. This map.ing aimed to establish the genesis of the relief through the correlation between materials, morphodynamic processes and estimated age, verifying the spatial arrangement of the system and their mutual relations. In addition to the use of morphological and morphometric data, it was necessary to add qualitative data marked in the field using geodetic GPS and automatic total station.

A preliminary investigation of the sampling areas was conducted in order to determine their morphometric characteristics and the nature of the superficial coverings (colluvial sediments or in situ regolith). This procedure has enabled the choice of sampling areas bearing stratigraphic characteristics that favored the reconstruction of the environmental dynamics of the area. Extensive trench digging was not need due to the ubiquitous occurrence of gullies radial or parallel to the axis of the slopes - cutting into the sedimentary deposits, revealing the entire thickness of the sediment layers, down to the contact with the underlying saprolite or rock basement. The morphostratigraphic framework was used as a guide to the sampling procedures. According to field evidences, an array of sampling techniques was defined in order to suit each sampling area, based on observed field relations between depositional units and their associated landforms.

The sampling procedures were structured following a combination of different strategies and techniques, aiming at the coverage of the different types of sedimentary deposits and lab techniques: stratigraphy and sediment macrofabrics; sedimentological properties, soil micromorphology and Scanner Electron Microscopy (SEM) of quartz grains; hillslope sediment dating and radiocarbon dating of charcoal fragments. The SEM of selected quartz grains (200 $\mu \mathrm{m})$ was performed at sub-samples extracted from those destined to grain size analysis. Sedimentologial and micromorphological analysis were conducted at GEQUA (Quaternary Geomorphology Lab) and the Environmental Electron Scanning Microscopy of the Federal University of Pernambuco.

Twenty black PVC tubes, $55 \mathrm{~cm} /$ length and $6.2 \mathrm{~cm}$ wide, with tight fitting lids were used for the sampling of sediments for OSL dating. The moisture content of the sediments was preserved for further laboratory analysis. Hence, the samples were carefully sealed in thin plastic film in order to avoid any loss of moisture during transportation. Sediments for dating were sampled from the same level as the material that was submitted to other sedimentological analysis, thus permitting an adequate chronostratigraphic correlation. A total of 15 samples were dated at the Luminescence Laboratory of the University of Durham, United Kingdom. Quartz grains were submitted to the SAR (Single Aliquot Regenerative) Protocol, with a total of 15 aliquots per sample. 
One charcoal sample from a colluvial fan was radiocarbon dated, thus enabling the crossing of the result with that obtained by OSL dating for the same stratigraphic level. The radiocarbon dating was conducted at Beta Analytics Lab, in the USA.

\section{THE SAMPLING AREAS}

The sampling was carried out in two geographically distinct areas, within the context of the Serra da Baixa Verde massif. The first sampling area was an elevated hollow, between 850 and 1100 meters of altitude. Two types of colluvial covers were observed in this area: a colluvial fan surrounding a convex elevation that formed gentle ramps that mingled downslope with the alluvial deposition from a stream channel, and a concave hollow, in the up.er segment of a zeroorder catchment, with segmented colluvial cover along the slope profile, exhibiting a concentration of material in the mid- and lower slope sections. Being situated on the summit surface of the massif both areas enjoy a tropical sub-humid climate with an average precipitation of $1300 \mathrm{~mm} /$ year (Figure 3).

Figure 3 - Sampling areas 1 and 2.

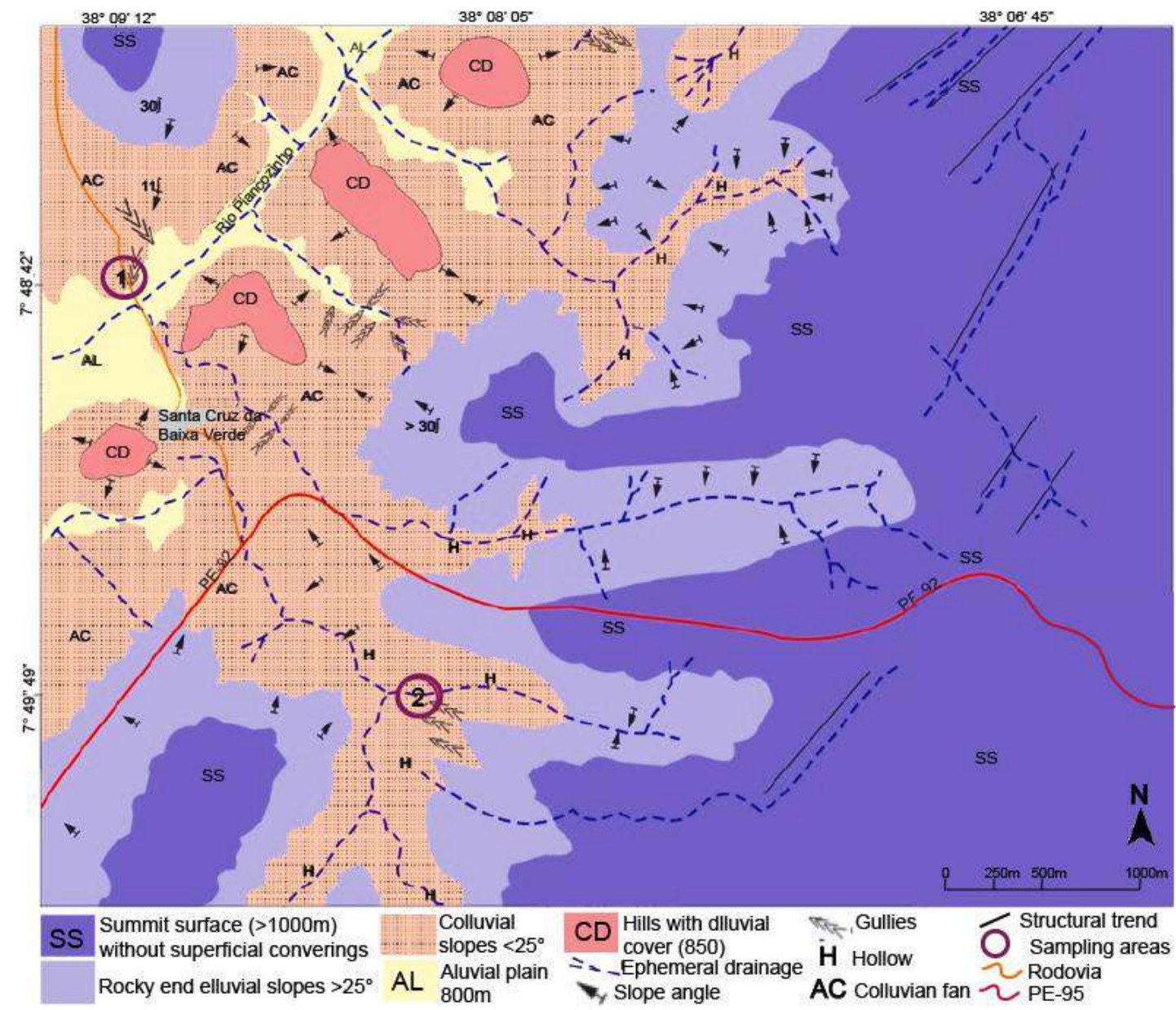

Source: the authors.

The second sampling area is located on the southern escarpment of the massif over colluvial fans that occur on the basis of some isolated elevations (spurs), that dot the front of the massif escarpment. The landform in question is a SW-NE trending, ridge-like, inselberg. 
Two sampling sites were chosen in this area: one on the southern tip of the inselberg, on the windward side of the landform, and another one on the northern face of the spur, in the rainshadow (Figure 4).

Figure 4 - Sampling areas 3 and 4.

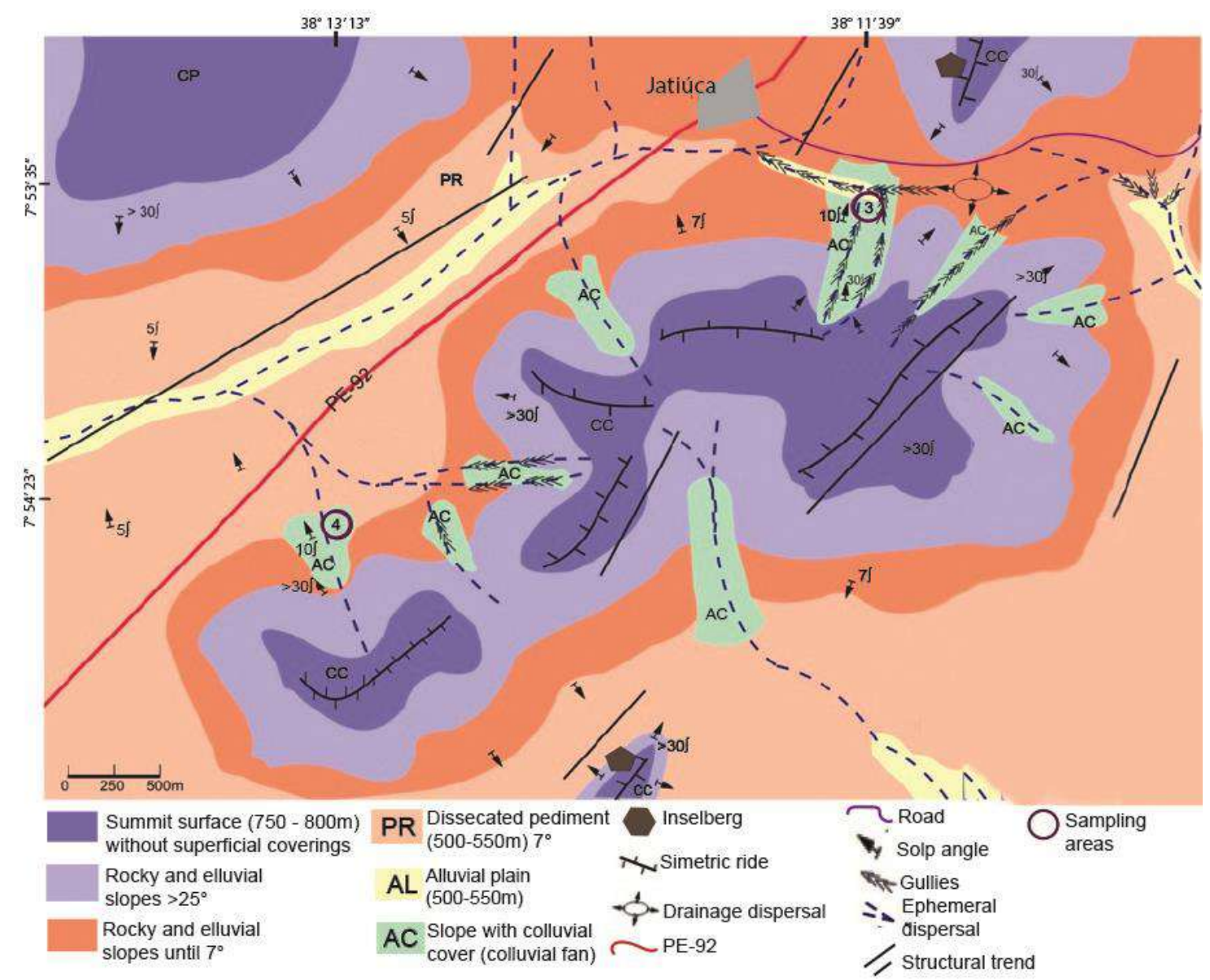

Digital elevation models (DEM) of the sampling sites were also generated adding to the overall visualization of the areas and potential morphostratigraphic relationship between accommodation spaces and colluvial covers (Figure 5). Initial relative age indication, in relation to the topographic position, of the colluvial unites were added to the DEMs. 
Figure 5 - DEM of sampling sites with relative age indication of colluvial units.
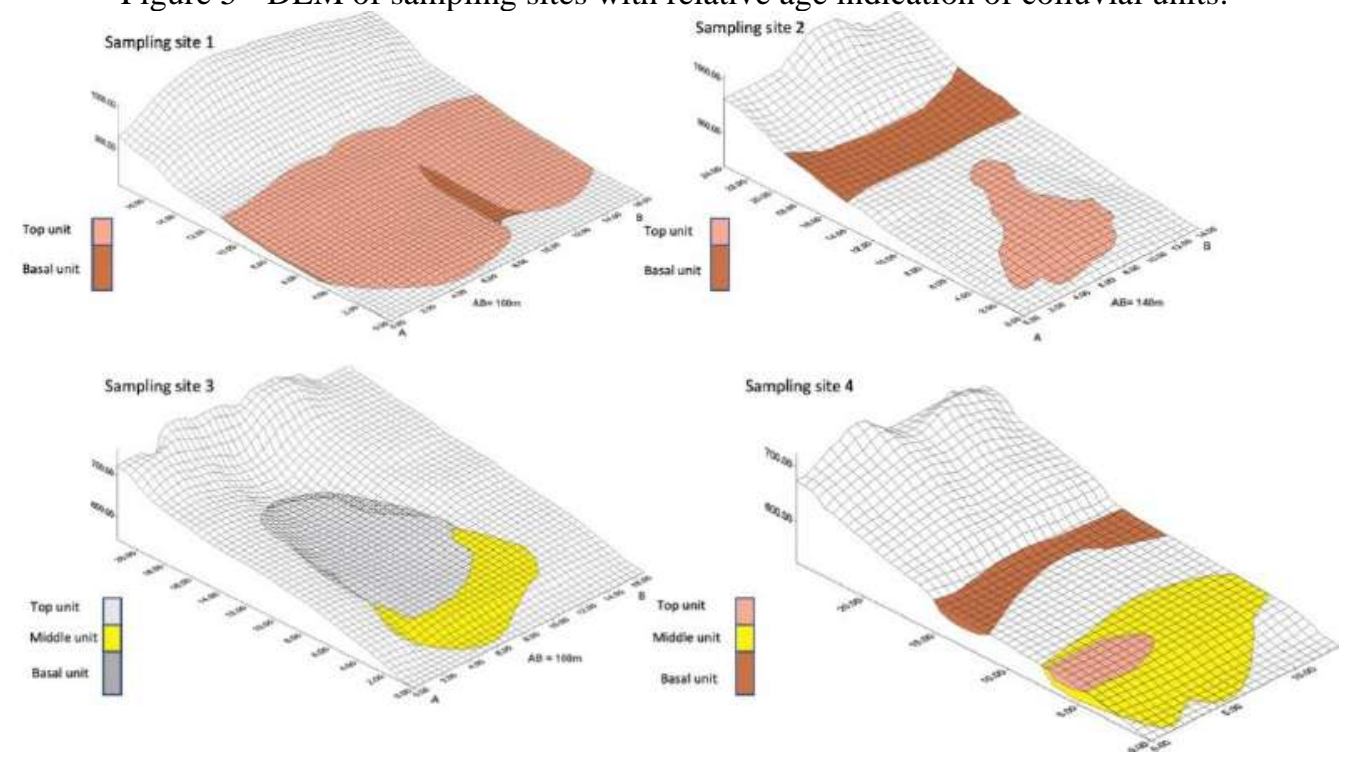

Source: the authors.

\section{SEDIMENTOLOGICAL ANALYSIS}

Colluvium from the sampled semi-arid and sub-humid slopes of the Serra da Baixa Verde massif showed little difference on its granulometric distribution, specially on the sand fraction, which indicates little variation in the sediment transport processes through time. The sand fraction is poorly sorted and its modal fractions show a predominance of the medium and fine fractions. Hillslope material was apparently accumulated by sheet-flood and gravitational flows. However, the stratigraphic subdivision of the hillslope sediments in discrete colluvial units based solely in field observation resulted unclear, possibly due to the degree of postdepositional geochemical alteration suffered by the material. Only the most recent units display primary depositional features such as laminated structures (Figure 6).

Figure 6 - Grain size distribution, in percentage, for each sampling point.

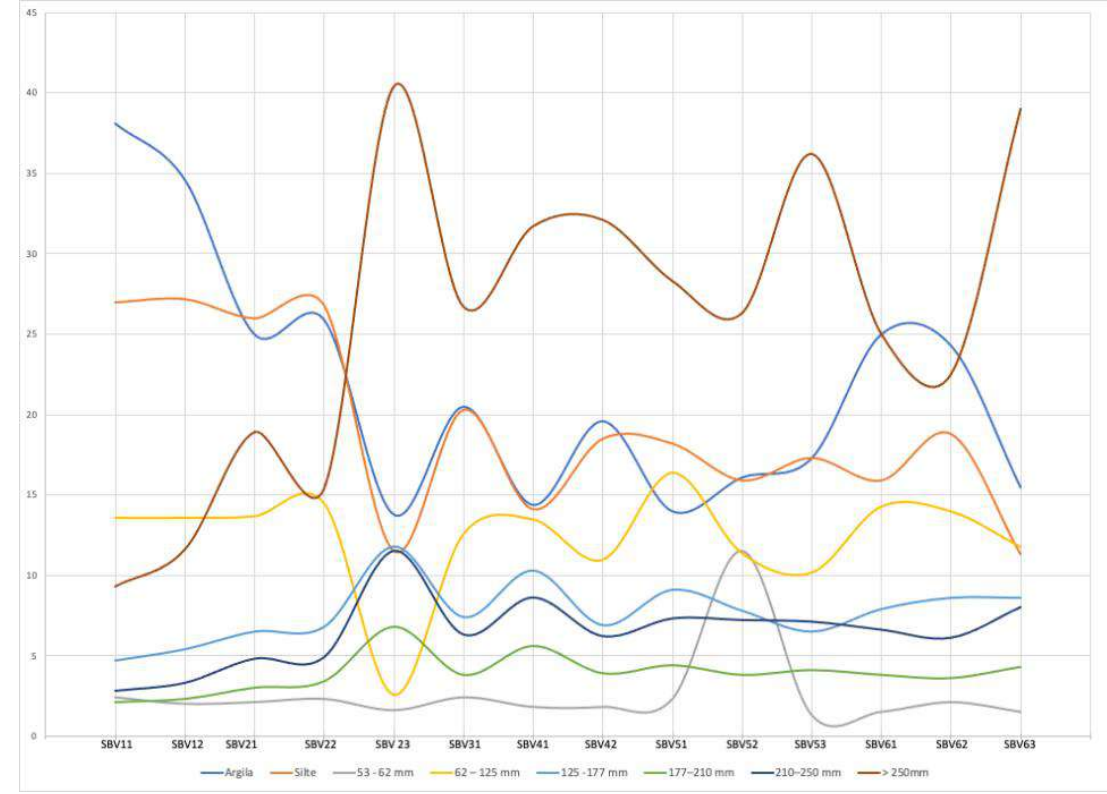

Source: the authors. 
The lack of well-preserved paleo-horizons may reflect the efficacy of sheet wash in remobilizing the topsoil. The occurrence of charcoal on the top of a buried stone-line, interpreted as a paleo-debris pavement may indicate that the erosive episodes took place under a sparse vegetal cover, similar to contemporary caatinga, with occasional bush-fires. The massive presence of K-feldspars in the sand fraction, mainly on the coarser fractions, points to a general abundance of these minerals in the parent rock. Quartz contribution ap.ears mostly in the finer fractions. The morphology of the quartz grains is inherited from the parental rock, in situ, showing little alteration by transport. Notwithstanding, scanning-electron-microscopy analysis of the surface of the quartz grains pointed to the efficacy of short distance transport in superimposing mechanical to chemical etching features on grain surfaces (Figure 7).

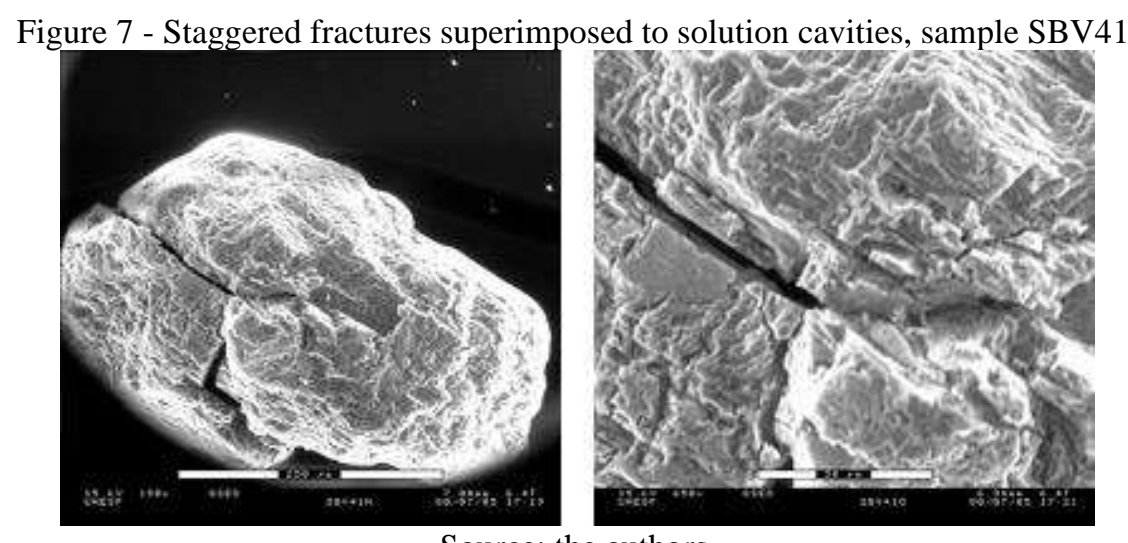

In all samples it was observed the abundance of material in distinct stages of chemical alteration, however the presence of fresh feldspar grains was remarkable. This characteristic also indicates that the material suffered a quick transportation, followed by the depositional isolation of the material. It seems that the time elapsed since the last depositional episode has not led to a mineralogical maturing of the sediments. In the semi-arid environment smectites, kaolinite and illite occur in almost constant ratios, whereas in the sub-humid environment, at the top of the massif, there is a predominance of kaolinite, with illite and montmorillonite ap.earing as accessories. Transport resistant pedofeatures such as petroplinthite have survived erosion and were preserved in the colluvium units like pedorelics, attesting to the transport and the occurrence of a ferruginization episodes prior to colluvium deposition (Figure 8).

Figure 8 - Fe nodule involving feldspar grains showing a post-depositional phase of Fe remobilization in the profile (Sample SBV11, magnification 40x).

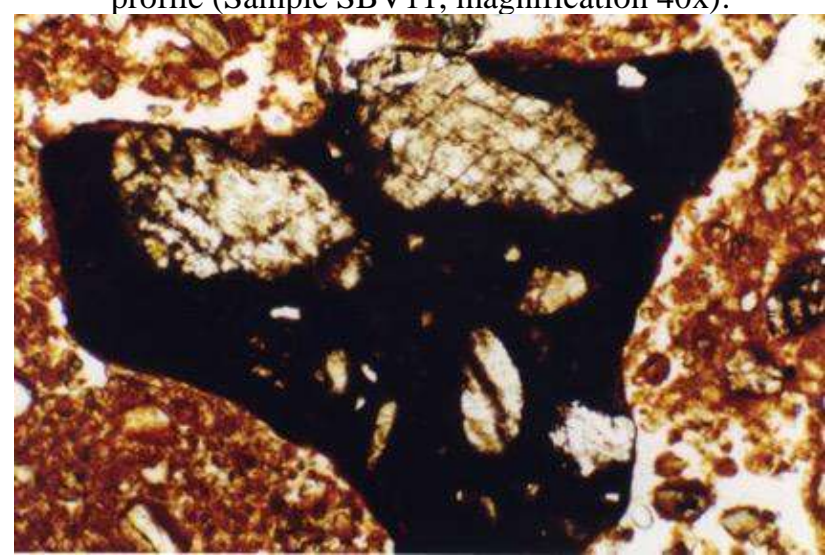

Source: the authors. 
It was observed that the downhill catenary distribution of soils was obliterated by erosional processes that created new depositional areas downslope of the source areas. The overall distribution of pedological properties: grain size, clay mineralogy, silt/sand ratio and cation exchange capacity (CEC) observed the catenary models envisaged by Thomas (1998) for sub-humid slopes under forest/savanna transition. The lower slope deposits, in the final reach of the zero order catchments, are mostly coarser, sandier and younger than those situated upslope, being the product of the reworking of the well-drained, ferruginized deposits of the middle slope, which generally contain a larger ratio of clay.

It is remarkable how the geometry of the deposits, their position on the slope and surface drainage determine the degree of profile evolution. Areas with ferricrete generally occur in the lower sections of the slopes, along the accompanying drainage lines along the valley bottoms. This suggests that the lateral inflow of water into the soil leads to iron enrichening of the lower and concave sectors of the slopes, possibly as a response to a seasonally higher water table along the stream channel, thus forming a hydromorphic ferricrete. Although the interpretation of lateritic crusts is out of the scope of this work, it is important to stress their occurrence in the area is restricted to the basal sectors of the sedimentary deposits, marking the transition to the parent rock along the valley bottoms. Thus, one cannot draw conclusions based on the existence of such hydromorphic duricrusts to justify the occurrence of regional scale climate variability. Under such circumstances, the crusts become an element of the functional pedological system, controlled by drainage and lithology (Figure 9).

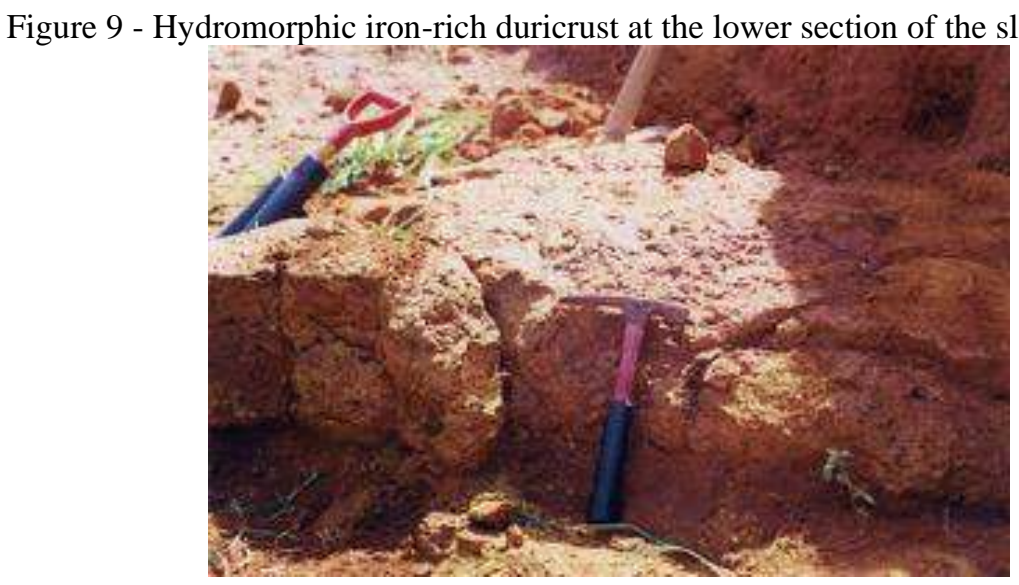

Source: the authors.

Much to the contrary of what one expects to find in tropical humid areas, colluvium from these elevated hollows of the Borborema Highlands have a very restrict spatial distribution and moderate thickness (rarely exceeding 2 meters). They tend to concentrate along the drainage axis of mountain catchments, locally leading to relief inversion by stream channel aggradation. Time also controls the pedogenetic evolution of these sedimentary storages, and, as the ratio of fines increases, these become more prone to remobilization. However, some specific trigger mechanisms must occur so that the removal of the material may effectively take place. Under contemporary deciduous arboreal vegetation cover, hillslope surface coverings are particularly resilient, and ubiquitous gravitational flows do not occur. On the other hand, gullying is pervasive on steep colluvial slopes under subsistence agriculture and pasture. 


\section{THE USE OF OSL (OPTICALLY STIMULATED LUMINESCENCE) AS A DATING TOOL}

The advantages of the OSL dating method over the other dating techniques of recent sediments, such as radiocarbon, derive from the fact that OSL explores a physical property luminescence - inherent to the crystalline solids (minerals) that constitute the deposit, primarily quartz and feldspar. Thus, OSL has become an important tool for the absolute dating of depositional events. Its temporal resolution ranges from ca. 100 years to 1Ma B.P., depending on the level of saturation of the material (AITKEN, 1998; WAGNER, 1998). Therefore, OSL is an optimal technique for the dating of depositional events that took place along the Quaternary; comprising regional climatic events of large magnitude (changes in regional circulation patterns), tectonic events affecting the drainage network (drainage inversions and captures due to uplift of catchments), and erosive episodes triggered by changes in the historical patterns of land use.

The luminescence dating techniques cover a range of methods based on the accumulation of radioactive charges, produced by a population of electrons prisoned in crystalline minerals. These methods are capable of stablishing the time elapsed since the prisoned electron population was liberated for the last time. The event of liberation of the accumulated charge is the instant when the material was exposed to daylight for the last time, before being buried by the deposition of another sedimentary layer. The technique has imposed itself since the middle 1980's, specially following the contributions of Huntley et al. (1985; 1988). The most significative finding was the possibility of measuring the luminescence signal directly related to the charge of the electron population imprisoned within the crystal, by a luminescent inducing, hence defining the OSL method itself (STOKES, 1999).

Electrons are freed from their steady state by an addition of energy to the system, like when they are exposed to ionizing radiation derived from radioactive decay. Once imprisoned, a part of the electron population can combine to defective areas in the mineral's crystal lattice, becoming stable, until a new addition of energy be introduced either by optical or thermal inducing (AITKEN, 1998). The OSL method assumes that any past electron charge contained within a sediment is substantially reduced, or completely removed, during the processes of erosion, transport and sedimentation (GODFREY-SMITH et al., 1988). Two main ap.roaches to the method are accepted, according to the wavelength of the luminescent source: IRSL, infrared stimulated luminescence, for K-feldspars and GLS, green-light stimulated luminescence for quartz.

Optical dating benefits from the fact that sunlight frees the electrons from sensitive traps that exist within the crystallographic structure of minerals such as quartz and feldspar, to name the most used for dating purposes. The liberation of the imprisoned electrons by a luminescent source reduces the OSL signal to zero. When the grains are buried and remain out of the reach of sunlight, they begin to accumulate a population of imprisoned electrons due to the effect of ionizing radiation emitted by the decay of radioisotopes within the deposit. A part of the natural radiation originates in the deposit itself (gamma radiation). If the flow of the radiation remains constant, so the time of burial can be determined by the measurement of the dose stored in the grains, divided by the flux of the environmental radiation (environmental dose).

As stated above, OSL can be used to estimate the time elapsed since the crystalline mineral components of a sediment were exposed to sunlight for the last time, therefore, the technique provides the age of the last stabilization of the deposit. Considering that the luminescence of natural minerals is a function of the exposition to environmental radiation, and 
that it can be zeroed by exposition to light during transport and deposition, the basic formula to calculate the age of the material can be expressed by the equation:

Age $=$ Palaeodose/Environmental Dose

The palaeodose is also referred to as equivalent dose (ED), and corresponds to the ionizing radiation derived from the decaying of the isotopes of uranium, thorium and potassium. One must still consider a minor contribution derived from cosmic radiation, to which the material has been exposed ever since deposition.

The environmental dose corresponds to the rate at which the sample was exposed to ionizing radiation, and therefore, to the rate at which the electron population accumulated. If the time interval considered equals to one year, one refers to this rate as the Annual Dose. The calculation of the annual dose can be complicated, attenuated by a number of factors such as: levels of environmental moisture, or chemical weathering, in such a way that its final formula is expressed as follows:

$$
\mathrm{D}_{\mathrm{a}}=0,92\left(\mathrm{D}_{\beta}\right) / 1+1,25 \mathrm{H}_{2} \mathrm{O}+\mathrm{D}_{\chi} / 1+1,14 \mathrm{H}_{2} \mathrm{O}+\mathrm{D}_{\mathrm{c}}+\left(\mathrm{D}_{\beta \mathrm{i}}\right)
$$

Where; $\mathrm{D}_{\mathrm{a}}$ (annual dose), $\mathrm{D}_{\beta}$ (beta radiation dose), $\mathrm{D}_{\chi}$ (gamma radiation dose), $\mathrm{D}_{\mathrm{c}}$ (cosmic radiation dose), $\mathrm{D}_{\beta \mathrm{i}}$ (internal beta radiation dose derived from $\mathrm{K}^{40}$ for $\mathrm{K}$-feldspar samples) and $\mathrm{H}_{2} \mathrm{O}$ (water content, expressed from 0 to 1 ).

The environmental dose, the measure of the ionizing radiation to which the mineral has been exposed, can be determined by several methods, such as: neutrons activation, $\beta$ TLD (beta radiation thermoluminescence dose) and high resolution gamma spectrometry which tests the occurrence of radioactive equilibrium within the deposit.

\section{Sample Treatment}

Sediment samples were extracted from PVC tubes in laboratory under subdued light conditions. Material from the extremities of the tubes was used to the measurement of the environmental dose, as well as for grain size, mineralogical analysis and determination of the moisture content. Following, the very fine sand fraction $(90-150 \mu \mathrm{m})$ was extracted through sieving. Samples were submitted to ultrasonic bath in deflocculating substance (sodium hexametaphosphate at 10\%). The grains were treated with a HF (hydrofluoric acid) solution at $40 \%$ for 60 minutes in order to remove the external $10 \mu \mathrm{m}$ layer of the quartz grains, according to Aitken (1998), thus eliminating the contribution of the $\alpha$ radiation to the calculation of the palaeodose. After the treatment with HF, samples were resieved and examined for mineralogical homogeneity.

Simultaneously, ap.roximately $60 \mathrm{~g}$ of material, from each sample, was separated from the extremities of the PVC tubes, and ground in a mechanical ball-mill for 15 minutes each. This material was reserved for the measurement of annual radiation dose by the methods of $\alpha$ radiation counting and $\beta T L D$ at the University of Durham Luminescence Lab facility.

The samples were then mounted on the top of $10 \mathrm{~mm}$ stainless steel disks, in single $1 \mathrm{mg}$ aliquotes. The disks were sprayed with silicon oil for better adherence. This material was subjected to the preliminary tests of observation of the natural signals of green/light and infrared OSL. 
Initial tests were carried out according to the following procedures: pre-heat at $260^{\circ}$ for $60 \mathrm{~s}$, in order to remove the charges from unstable traps, measurement of OSL at $110^{\circ}$ for $250 \mathrm{~s}$ of greenlight illumination. The infrared luminescence was measured after pre-heating the samples at $220^{\circ}$ for $10 \mathrm{~s}$. The measurement was conducted at $75^{\circ} \mathrm{C}$. The presence of a strong IRSL signal, in most of the samples, suggested contamination by feldspars and, then, samples were submitted to heavy liquid separation - sodium poly-tungstate, 2,7 to $2,6 \mathrm{~g} / \mathrm{cm}^{3}$, to concentrate quartz. Material with densities ranging from 2.58 to $2.65 \mathrm{~g} / \mathrm{cm}^{3}$ was tested for IRSL. However, due to the impossibility of completely removing the feldspars, samples were separated in two batches: quartz samples were dated by green-light stimulated luminescence, and IRSL was used for k-feldspar samples.

All samples were analyzed by cathodoluminescence in order to determinate the origin of the infrared luminescence emissions, as well as for testing the efficacy of the heavy liquid separation and avoid contamination of samples destined to OSL green-light measurements by feldspar grains. Quartz emits a negligible infrared luminescence, however, potassic feldspars, which are very abundant in the syenite of the Baixa Verde massif, emit a strong green-light luminescence, thus contaminating the quartz samples. In order to correct the $\beta$ radiation internal dose for the feldspar samples, originating from ${ }^{40} \mathrm{~K}$, the potassium content of these samples was determined by ICP-AES.

The fact that the initial IRSL values obtained for some samples had not substantially changed for tests conducted in polymineralic fractions (density $<2,6 \mathrm{~g} / \mathrm{cm}^{3}$ and between 2,6$2,7 \mathrm{~g} / \mathrm{cm}^{3}$ ), suggested that the mineralogy of these samples had remained relatively unchanged after heavy liquid separation attempts. This evidence has also helped select feldspar rich samples. Samples for IRSL dating, infrared luminescence, were re-selected and treated with an HF solution at $10 \%$, to avoid the dissolution of feldspars beyond the desired level. The impregnation by iron oxide was attenuated through non-aggressive wash treatments - CBD method.

Soluble fluorides and organic matter were eliminated by a treatment with a $\mathrm{HCl}$ solution at $15 \%$. All luminescence analyzes were performed by automated TL/OSL RIS $\varnothing$ sets, with a photomultiplier tube EMI 9635QA, a green-light source of (420-450 nm), and filters adjusted both to infrared and greenlight stimulation. Tests were conducted with the use of a 4.65 version of RIS $\varnothing$ TL/OSL software.

One milligram sediment samples were mounted on stainless steel disks, previously sprayed with silicon oil, and analyzed according to the protocol developed by Roberts et al. (1998). The luminescence signal was measured at $125^{\circ} \mathrm{C}$. OSL natural dose was chosen to match the lowest natural signal according to Olley et al. (1998).

Quartz samples destined to green-light OSL were submitted to the SAR protocol - Single Aliquot Regeneration, as defined by Aitken (1998). In this procedure, after measuring the natural luminescence, a series of radiation doses are given to the sample in order to regenerate the original luminescence signal. The procedure is repeated for a reduced number of aliquots (15 per sample), and finally the weighted mean of the palaeodoses is obtained, through the interpolation of the value of the natural luminescence, over the line that joins the points obtained by the regenerated doses, given in laboratory.

The procedures used for dating the IRSL (feldspar) samples, to contrary of the green-light OSL, were based on the method of the multiple aliquots additive dose. The reason for this choice lies in the intrinsic characteristics of feldspar crystals, that may exhibit a great variation in sensitivity when subjected to the regenerative method. In the additive dose method, a number of aliquots, per sample, is prepared and split into smaller batches. One of such batches is put aside for the measurement of the natural luminescence, whereas the other batches are given 
several, pre-defined, artificial radiation doses in laboratory, before proceeding any type of measurement. For this purpose, a number of 20 aliquots per sample was used. Thus, an artificial dose is added to the natural, pre-existing, dose. Finally, the potassium content was measured for each treated sample to be subjected to the IRSL measurements. This procedure should correct the dose value derived from the excess internal ${ }^{40} \mathrm{~K}$ contribution in the feldspar grains. The measured values remained constant and relatively high, in average a 3-fold the expected value for colluvium, ranging from $10 \%$ to $12 \%$ per sample. The high potassium content might account for the strong luminescence signal observed in most samples, even very young ones.

\section{DETERMINATION OF THE ANNUAL DOSE}

There are several techniques for the assessment of the annual dose. Once the concentration of potassium, uranium and thorium is known, the annual dose can be calculated. For this purpose, conversion factors are used, that provide the radiation dose for a quasi-infinite matrix per unit of concentration. In this work, the corrected factors provided by Adamiec \& Aitken (1998) were used. The contribution of cosmic rays was estimated according to the depth of the material, altitude and latitude of the sampled area.

The annual dose can be calculated according to the following simplified formula:

$$
\mathrm{D}_{\mathrm{a}}=\mathrm{D} \beta+\mathrm{D} \chi+\mathrm{D}_{\mathrm{c}}+\mathrm{D} \beta_{\mathrm{i}}
$$

Where, $\mathrm{D}_{\mathrm{a}}$ - Annual dose; $\mathrm{D} \beta$ - beta dose; $\mathrm{D} \chi$ - Gama dose; $\mathrm{D}_{\mathrm{c}}$ - cosmic dose and $\mathrm{D} \beta_{\mathrm{i}}$ - internal beta dose derived from ${ }^{40} \mathrm{~K}$, for the K-feldspar samples dated by IRSL.

However, the value of the beta dose must be attenuated multiplying it by the constant 0.92 (AITKEN, 1998). It is also necessary to consider the moisture content of the sediments, which interferes with the values of the beta and gamma radiations. At last, the equation for the calculation of the annual dose takes the following shape:

$$
\mathrm{D}_{\mathrm{a}}=0,92(\mathrm{D} \beta) / 1+1,25 \mathrm{H}_{2} \mathrm{O}+\mathrm{D} \chi / 1+1,14 \mathrm{H}_{2} \mathrm{O}+\mathrm{D}_{\mathrm{c}}+\mathrm{D} \beta_{\mathrm{i}}
$$

Where, $D_{a}-$ Annual dose; $D \beta$ - beta dose; $\mathrm{D} \chi$ - Gama dose; $\mathrm{D}_{\mathrm{c}}-$ cosmic dose and $\mathrm{D} \beta_{\mathrm{i}}-$ internal beta dose derived from ${ }^{40} \mathrm{~K}$ for the $\mathrm{K}$-feldspar samples dated by IRSL and $\mathrm{H}_{2} \mathrm{O}-$ moisture content from 0 to 1 . In this study the adopted methods for obtaining the levels of beta and gamma radiation (once the alfa radiation contribution was eliminated by the HF treatment of the grains) were the neutrons activation analysis (NAA), $\beta$ TLD (dosimetry of the $\beta$ thermoluminescence) and alfa radiation counting.

The results obtained for all palaeodoses were treated by the weighted means method. Following, an error analysis was performed for all parameters considered. In this stage, it became ap.arent that the Annual Dose remained constant in both methods used to calculate beta and gamma radiation - neutrons activation and $\beta T L D$ and alfa counting. The only discrepancy was found in sample OBV11, but due to the constancy of the values obtained by $\beta T L D$, it was chosen to consider this value as the correct one for the annual dose of the sample; all the remaining samples had their annual dose calculated by neutrons activation (table 1).

On the top of a gravelly layer, $50 \mathrm{~cm}$ thick, a sample was collected for luminescence 
dating. Amidst the sediments, several fragments of charcoal, of variable sizes, were found. Altogether $100 \mathrm{~g}$ of charcoal were recovered and preserved for radiocarbon dating. The fragments were evenly spread and did not show lateral continuity, in such a way it could suggest they belonged to a contemporary carbonized root. However, the occurrence of charcoal was not observed in any other layer of the same profile, nor in any other sampling area. The sample was sent to Beta Analytic laboratory, in the United States of America, which resulted in a radiocarbon date of $9240 \pm 70$ a BP. This value is very close to that obtained by OSL for the top of the gravelly layer, which was $8,5 \pm 2,5 \mathrm{Ka} \mathrm{BP}$ (SBV52). The base of the gravelly layer, $55 \mathrm{~cm}$ bellow the top, rendered an equally similar age, yet with a smaller standard deviation, $8.94 \pm 0,58 \mathrm{Ka} \mathrm{BP}$ (SBV51). This indicates that the gravelly layer in question was deposited as one discrete episode about 9000 years BP. This fact would explain the negligible age difference between the base and the top of the gravelly layer, less than 500 years (Figure 10).

Table 1: Age calculation for quartz and feldspar dated samples

\begin{tabular}{|c|c|c|c|c|c|c|c|c|c|c|c|c|c|}
\hline PARAMETERS & SBV11 & SBV12 & SBV22 & SBV23 & SBV31 & SBV41 & SBV42 & SBV51 & SBV52 & SBV53 & SBV61 & SBV62 & SBV63 \\
\hline $\begin{array}{c}\text { Palaeodose } \\
\text { (Gy) }\end{array}$ & $\begin{array}{r}183,5 \\
\pm 64,6 \\
\end{array}$ & $\begin{array}{c}77,9 \pm \\
19,4 \\
\end{array}$ & $50,6 \pm 5$ & $\begin{array}{c}2,2 \pm \\
0,18 \\
\end{array}$ & $\begin{array}{c}60,1 \\
\pm 13,9 \\
\end{array}$ & $\begin{array}{c}63,6 \pm \\
23,1 \\
\end{array}$ & $\begin{array}{c}66,1 \pm \\
2,4 \\
\end{array}$ & $83 \pm 4,3$ & $\begin{array}{c}90,1 \pm \\
28,1 \\
\end{array}$ & $\begin{array}{c}43,1 \pm \\
2,4 \\
\end{array}$ & $\begin{array}{c}60,3 \pm \\
9,9\end{array}$ & $\begin{array}{c}69,6 \pm \\
1,7 \\
\end{array}$ & $\begin{array}{c}0,87 \pm \\
0,1\end{array}$ \\
\hline $\begin{array}{c}\text { Internal } \beta \text { Dose } \\
(\mathrm{Gy} / \mathrm{Ka})\end{array}$ & 0,4 & 0,4 & - & - & 0,4 & 0,4 & - & - & 0,4 & - & 0,4 & - & - \\
\hline$\beta$ Dose $(\mathrm{Gy} / \mathrm{Ka})$ & 5,8 & 4,6 & 5,5 & 6,95 & 5,6 & 6 & 6,3 & 6,5 & 7,2 & 6,3 & 5,6 & 5,6 & 6,6 \\
\hline$\chi$ Dose $(\mathrm{Gy} / \mathrm{Ka})$ & 3 & 1,9 & 2,1 & 2,7 & 2,2 & 2,3 & 2,4 & 2,5 & 2,7 & 2,4 & 2,4 & 2,3 & 2,6 \\
\hline $\begin{array}{l}\text { Cosmic Dose } \\
(\mathrm{Gy} / \mathrm{Ka})\end{array}$ & 0,18 & 0,2 & 0,22 & 0,22 & 0,21 & 0,18 & 0,22 & 0,18 & 0,19 & 0,21 & 0,21 & 0,2 & 0,23 \\
\hline $\begin{array}{c}\text { Moisture } \\
\text { Content \% }\end{array}$ & 8,3 & 6,7 & 7,1 & 4,6 & 7,1 & 4,4 & 5,7 & 4,9 & 4 & 4,7 & 4,3 & 4,8 & 3,3 \\
\hline $\begin{array}{c}\text { Annual Dose } \\
(\mathrm{Gy} / \mathrm{Ka})\end{array}$ & $\begin{array}{c}8,98 \pm \\
3,2\end{array}$ & $\begin{array}{c}7,3 \pm \\
3,5\end{array}$ & $8 \pm 3,7$ & $\begin{array}{c}10 \pm \\
3,7\end{array}$ & $8,5 \pm 3,5$ & $9 \pm 3,6$ & $\begin{array}{c}9,1 \pm \\
3,7\end{array}$ & $9,3 \pm 3,7$ & $\begin{array}{c}10,6 \pm \\
3,6\end{array}$ & $\begin{array}{c}9,1 \pm \\
3,7\end{array}$ & $8,7 \pm 3,5$ & $\begin{array}{c}8,3 \pm \\
3,6\end{array}$ & $\begin{array}{c}9,6 \pm \\
3,7\end{array}$ \\
\hline $\operatorname{AGE}(\mathrm{Ka})$ & $\begin{array}{c}20,4 \pm \\
7,2 \\
\end{array}$ & $\begin{array}{c}10,6 \pm \\
2,6 \\
\end{array}$ & $6,3 \pm 0,6$ & $\begin{array}{c}0,24 \pm \\
0,02 \\
\end{array}$ & $7,1 \pm 1,6$ & $7,1 \pm 2,5$ & $\begin{array}{c}7,2 \pm \\
0,3 \\
\end{array}$ & $8,9 \pm 0,5$ & $\begin{array}{c}8,5 \pm \\
2,6 \\
\end{array}$ & $\begin{array}{c}4,7 \pm \\
0,3 \\
\end{array}$ & $6,9 \pm 1,1$ & $\begin{array}{c}8,4 \pm \\
0,3 \\
\end{array}$ & $\begin{array}{c}0,11 \pm \\
0,01 \\
\end{array}$ \\
\hline
\end{tabular}

Dating of a charcoal sample by radiocarbon

Source: the authors.

Figure 10 - Charcoal fragments atop of a gravelly layer (SBV51).

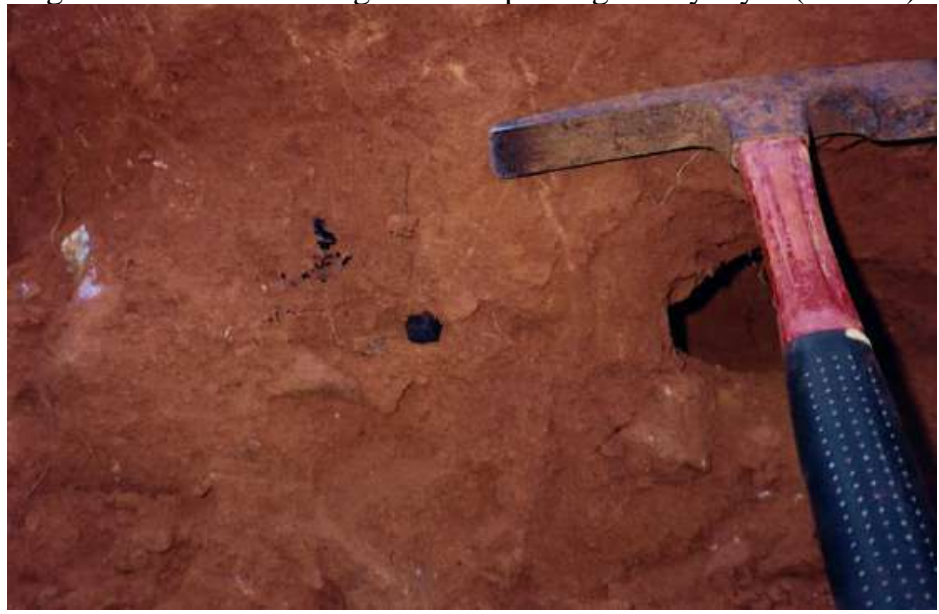

Source: the authors. 


\section{RECONSTRUCTION OF THE ENVIRONMENTAL DYNAMICS}

Based on the sedimentological evidences, OSL dating and the detailed geomorphological map.ing it was feasible to put forward a qualitative reconstruction of the several colluvial deposition scenarios observed at the Baixa Verde Massif. Models were created in order to give an account of the geomorphological dynamics in the area, since the Last Glacial Maximum (LGM).

Area 1 - In this sampling area, a simple superposition of events was observed: a basal conglomerate lies underneath a fine red colluvium, the deposition interval between both units reached, at least, 10.000 years. The dates coincide with important events of regional landscape reorganization: the LGM and the Pleistocene/Holocene transition. The processes involved in deposition were debris flows, which account for the basal gravelly layer, and mudflows, as well as sheet wash, which may have originated the red colluvium on the top of the sequence. Both units exhibit a stronger pedological maturity as compared to the other sampled areas, which corroborates the temporal subordination of pedogenesis in the area. The overlying unit, however, showed a smaller degree of mineralogical maturity, which was evidenced by the clay mineralogy and its younger age. The primary depositional features are lacking in both units, the only exception being the basal conglomerate/gravelly layer. The occurrence of indurated levels and duricrusts was restricted to the basal conglomerate, along the base of the slope which is cut by a stream channel (Figure 11).

Figure 11 - Log section of sampling area 1.

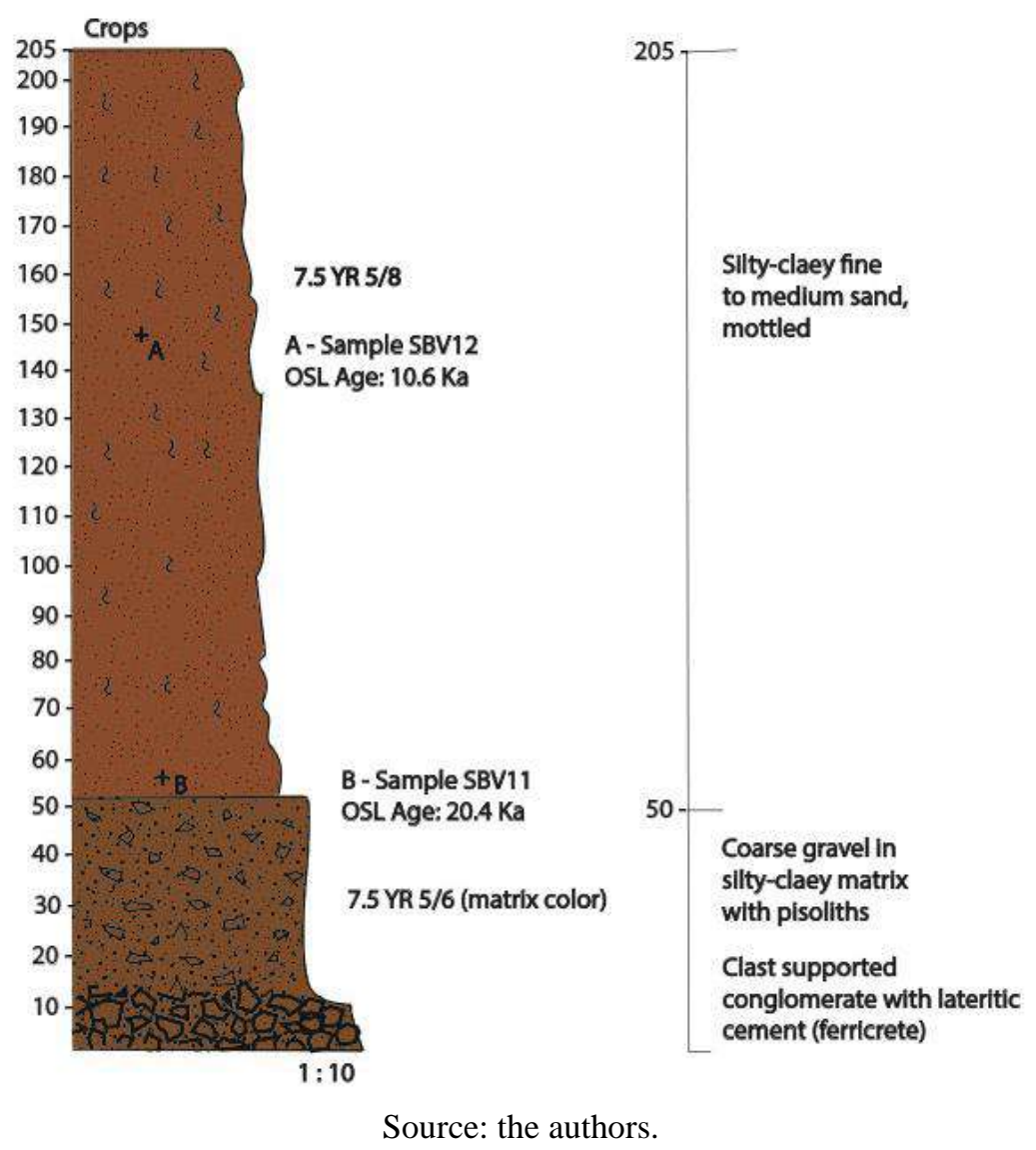


Area 2 - The second sampling area, an elevated hollow within the sub-humid domain of the massif showed a spatial distribution of depositional units adjusted to a concave slope morphology. Two distinct depositional areas were identified: one on the knick point of the slope along its intermediate sector, and a second one at the base of the slope. The up.er unit is mineralogically mature, and the colluvial material is almost identical to the underlying saprolite in terms of pedogenic characteristics. This level has rendered an OSL age of 6,3 Ka BP, which suggests the occurrence of a mid-holocene depositional event, that remained preserved within a small concave accommodation space in the mid-slope sector.

The lower slope deposit is clearly a result of reworking of the upslope material. Its superficial morphology still displays a lobate shape, suggesting the occurrence of a localized colluvial fan, probably the result of the buildup of several mudflow/laminar flow episodes. The 240 years BP OSL age of this deposit indicates the possible interference of human impacts in the area triggering the depositional event. This date coincides with the European settlement of the area and the eradication of the native montane forest for the introduction of coffee plantations. Unlike the material from the mid-slope sector, the younger unit exhibit remains of primary depositional features such as layers of alternating granulometry (Figure 12).

Figure 12 - Log sections of sampling area 2.

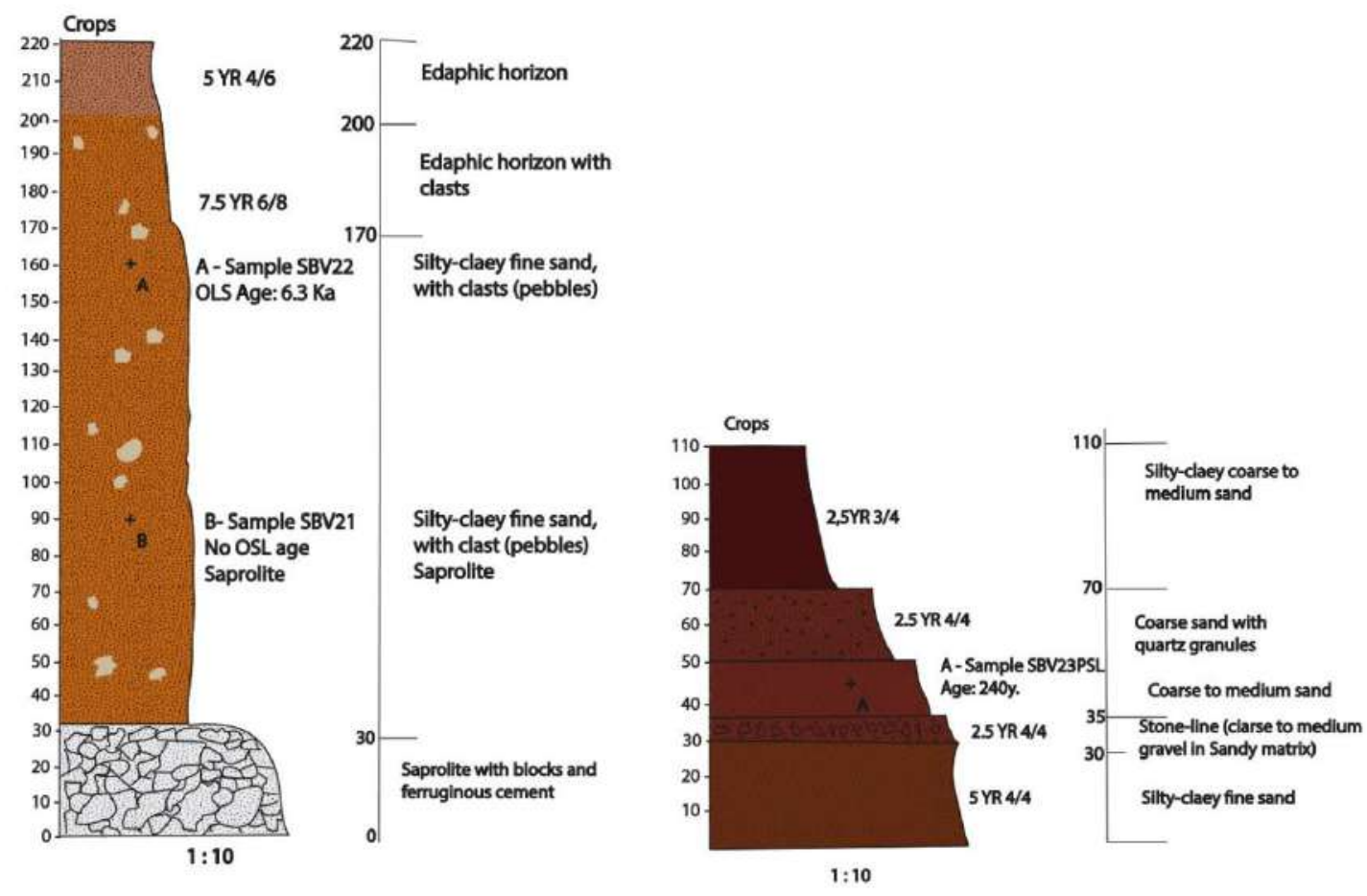

Source: the authors.

Area 3 - The third sampling area, a colluvial fan, forms a detritical pediment within the semiarid lowlands that surround the massif , along its souther escarpment. This site has showed a more complex sequence of depositional events, that permitted a better assessment of the environmental circunstances involved with the erosive episodes. Another peculiar characteristic of this site is the relative mineralogical imaturity of the sediments, as well as the occurrence of different types of depositional processes. The hillslope sediments contais pedo- and litho-relicts which help interpret the conditions prevailing prior to the onset of colluviation in the site. The matrixes of the sediments also are good agreement with debris flows. 
Along the deeply incised gullies that cut through the sediment it was possible to observe the occurrence of several colluviation events, separated by gravely layers of varied thicknesses. The resulting ages showed a good spatial coherence; the oldest ones being refferred to upslope position and a greater depth. This evidence has indicated that the material suffered a continuous reworking alonge the slope, possibly triggered by a series of short-distance debris and mudflows, as well as sheet-flow erosion. Ap.arently this slope had been active throughout the lower and mid-Holocene, with a halt in sedimentation occurring around $4 \mathrm{Ka} \mathrm{BP}$.

The oldest unit, ca. 9ka BP - whose OSL age was corroborated by a radiocarbon dated charcoal fragment from the same stratigraphic level - lies close to the slope knick-point, at 160 $\mathrm{cm}$ from the surface. The unit is a $50 \mathrm{~cm}$ thick gravelly layer, on the top of which the charcoal fragments were found, attesting to the former situation of the layer as a former geomorphic surface, which evolved to a debris pavement by sheet flow action, , as well as was prone to the occurrence of range fires in the beginning of the Holocene. The unit that covers the gravelly layer is ap.roximately 1 meter thick and has yelded an age of ca. $4.7 \mathrm{Ka} \mathrm{BP}$, which atests that a substantial depositional (erosional ?) interval took place in the break of the slope. This unit display a massive structure lacking larger clasts.

The other two sampled stratigraphic profiles from this area, come from a pediment ramp at the slope base, dissected by a gully. Both profiles displayed rudaceous layers in between finer colluvial units. Sample SBV 41 showed a macrofabric characteristic of a debris flow terminal lobe with blocks imbricated downslope. The top sample came from a well defined discontinuity between two finer, red, massive colluvial units. The discontinuity between them was marked by a stone-line, which were also imbricated downslope.

The OSL ages for both low slope samples were very similar, indicating a sequence of mud- and debris-flows ocurring around $7 \mathrm{ka} \mathrm{BP}$ (Figure 13). Since this age was not registered at the mid-slope profile, it is possible to postulate the hypotheses that these deposits, situated downslope from the first, result from reworking of the older upslope ones, from the lower Holocene. The sequence displays a sort of incomplete slope transfer sediment cascade, with younger sediments only partly overlap.ing the older units. The depositional mode, dominated by mud flows, has generated rather homogeneous colluvium layers. However, buried paleosurfaces were still discernible by micromorphological analysis, as some levels display a concentration of coarser fractions, and a loss of the finer matrix.

Figure 13 - Log sections of sampling area 3.
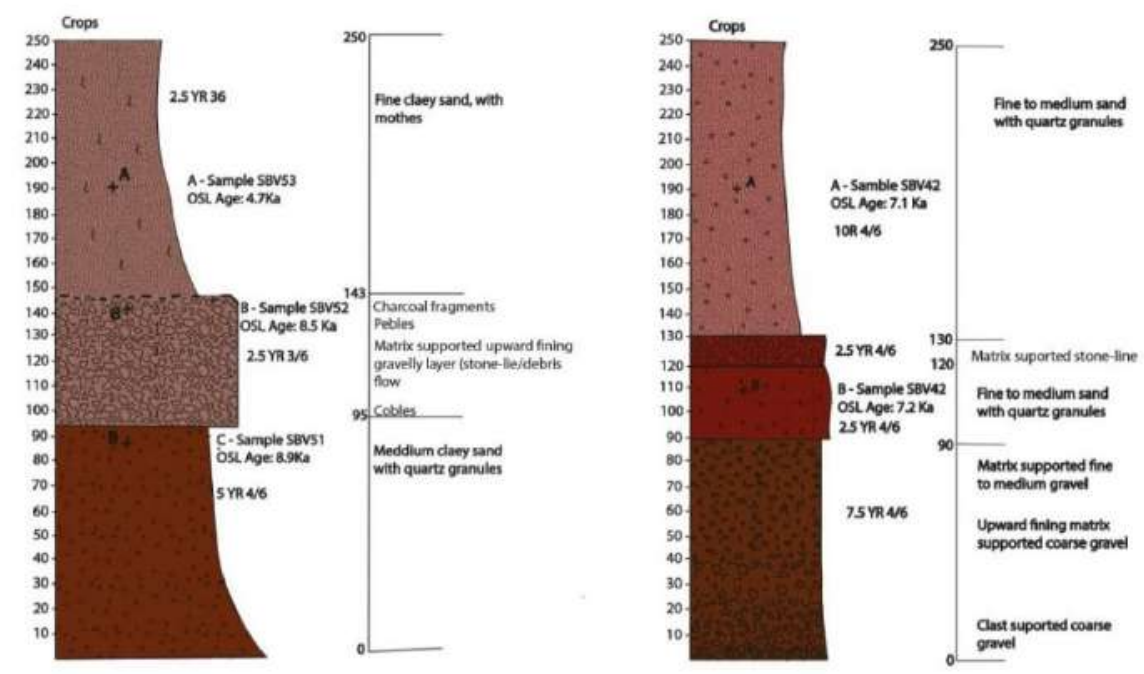

Source: the authors. 
Area 4 - The 4th sampling area is a classical pediment, with a sharp knickpoint separating it from the higher gradient upslope area. It is located on southern edge of the same inselberg ridge of area 3. The sediment cover occurrs in the shape of local infillings of paleo-concavities and channel incisions. Deposition on those former accomadation spaces has evolved to generate local relief inversions.

The site displays a deposition pattern that resembles those from sampling areas 2 and 3. Sediments are mineralogically mature in spite of the contemporary semi-arid conditions prevailing in the area. In this case a combination of factors may have contributed to the mineralogical maturity of the deposit: the gentle inclination of the slope, which has facilitated the free drainage of the material and its windward situation, whereas Area 3 lies in the rainshadow of the elevation, thus receiving much less precipitation.

The depositional units are discontinuously distributed along a pediment ramp. Two sediment storage areas are separated by a rocky pediment structured on slightly weathered syenite saprolite. From top to bottom, the first area lies on the concavity of the slope knickpoint. It is a fine red colluvium containing ferruginous nodules pedo-relics (SBV 62). Another unit, a clast sup.orted gravelly layer, lies under the fine red colluvium, probably filling the incision of a paleo-channel. This rudaceous deposit represents the basal unit of a gently sloping pediment ramp, as colluviation has completely altered the original paleotopography of the area (Figure 14).

Figure 14 - Local relief inversion by colluvial infilling of a paleo-channel. Yellow line represents the paleotopography.

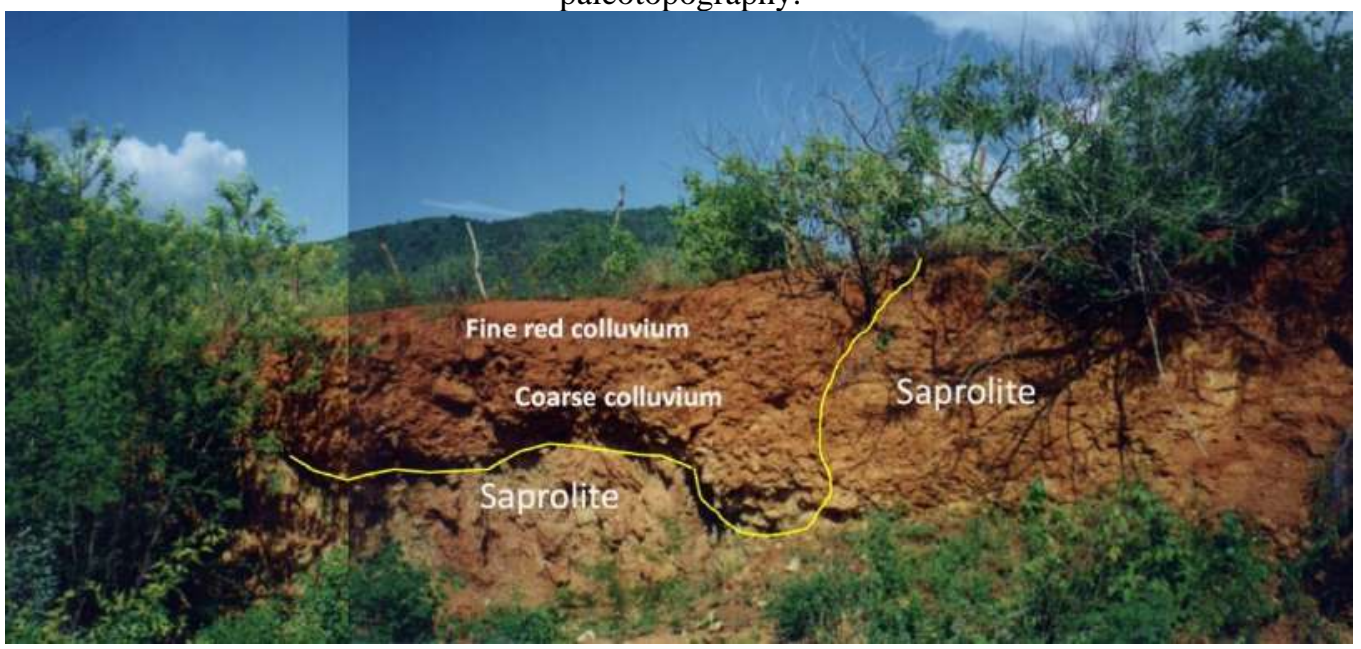

Source: the authors.

A small concavity in the mid-slope section of the rocky pediment is filled with a $60 \mathrm{~cm}$ layer of finely laminated sediment (Figure 15). This material lies on the top of the basal gravelly layer, in a sector where the fine red colluvium layer is lacking (SBV 61).

The OSL dates obtained for these three units atest to the episodical character of colluviation in the region, with well marked depositional pulses still preserved in landscape, despite being spatially disconnected. The gravelly basal layer, with an age of $8.4 \mathrm{Ka} \mathrm{BP}$, points to the occurence of a high energy erosive episode at the beginning of the Holocene, which has produced a general reworking of the pleistocenic rudaceous weathering mantles. This age is coincident with the wide-spread colluviation at the semi-arid Northeast and points to a teleconexion with a well documented Northern Hemisphere cooling event (CHANG et al., 
2009, OLIVEIRA et al., 2020). The red colluvium, by its turn, is related to the pluvial event of the mid-Holocene (AMORIM et al., 2020), with an average age of $6.9 \mathrm{Ka} \mathrm{BP}$, whereas the layer of finely laminated sediment yelded an extremely young age, ca. 110 years BP.

Figure 15 - Log sections of sampling area 4.
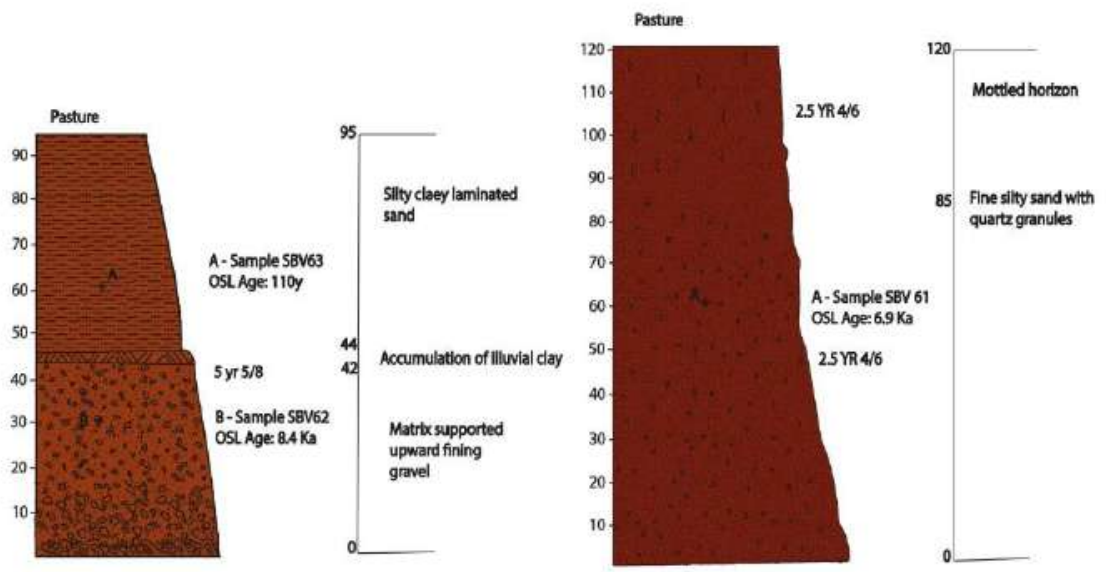

Source: the authors.

The very recent age of the laminated colluvial unit points to the pulsating nature of the Serra da Baixa Verde massif geossystem surface dynamics, and possibly reflects the extremely rainny episodes of the early 1910's that followed the long lasting droughts of the last quartile of the $19^{\text {th }}$ century and first decade of the $20^{\text {th }}$ - the most severe reported in the region in historical times. In this case, hillslope sedimentation is linked to short term recurring climatic events such as ENSO and the Atlantic dipole, whose inprint in the semi-arid landscape of Brazil has only recently been aknowledged (AMORIM et al., 2020).

\section{FINAL CONSIDERATIONS}

The absolute dating of the slope sediments has enabled the identification of a substantial difference between the real age of surface coverings and the inferred ages of the erosional surfaces under which these deposits are found as proposed by the classical denudation chronology ap.roach. A detailed chronology of the geomorphological events leading to hillslope sediment accumulation in the Serra da Baixa Verde massif could not have been accomplished without the use of OSL. Thus, this study demonstrates that the ap.lication of sediment absolute dating techniques, combined with detailed surface coverings analysis, shall enhance the understanding of the temporal component of geosystems.

In the present case study, colluviation events along the slopes display a pulsatile pattern, related to trigger mechanisms operating at different timescales since the LGM. The presence of human induced depositional events points to a direct link between land use changes and shortterm climatic variability. In this case erosive/depositional couplets may be triggered by ENSO and other short cycle phenomena.

In a broader perspective, it was observed that the regional morphoclimatic system, semiarid tropical, and its behavior since the LGM has imprinted a peculiar character to local hillslope sediment output and the processes involved in the transference of eroded material across the landscape. The massif's depositional environment is characterized by thin and spatially disjunct colluvial deposits displaying incipient pedogenetical evolution as compared 
to humid tropical counterparts. Lithofacies point to the prevalence of gravity flows (mud- and debris-flows) and secondarily sheet-flow deposits. The absence of colluviation older than the LGM suggests that the hillslope sediment storage is relatively short-lived, which points to a much faster overall geomorphic dynamic than previously assumed.

\section{REFERENCES}

ADAMIEC, G.; AITKEN, M. Dose-rate conversion factors: update. Ancient TL, 16, 1998, p. 14. Fonte: http://ancienttl.org/ATL_16-2_1998/ATL_16-2_Adamiec_p37-50.pdf.

ADAMS, J.; MASLIN, M.; THOMAS, E. Sudden climate transitions duringthe Quaternary. Progress in Physical Geography, 23(1), 1999, p. 1-36. doi:10.1177/030913339902300101.

AITKEN, M. J. An Introduction to Optical Dating: the dating of Quaternary sediments by use of Photon-stimulated Luminescence. Oxford University Press, 1998.

AMORIM, R. F.; CORRÊA, A. B.; MUTZENBERG, D. S.; MEIRA, D. A. Evolução holocênica das encostas da bacia do riacho Bruscas, Nordeste do Brasil. Revista do Departamento de Geografia, 39, 2020, p. 112-125.

AZAMBUJA, R. N.; CORRÊA, A. B. Dinâmica superficial em uma bacia de drenagem semiárida mediante o uso do césio-137: estudo de caso da bacia do riacho Salgado-PE. GEOUSP, 24(2), 2020, p. 1-30.

BIGARELLA, J.; MOUSINHO, M. R. Considerações a respeito dos terraços fluviais, rampas de colúvio e várzeas. Boletim Paranaense de Geografia, 17, 1965, p. 153-197.

CHENG, H.; FLEITMANN, D.; EDWARDS, R.; WANG, X.; CRUZ, F. W.; AULER, A. S.; . . MATTER, A. Timing and structure of the $8.2 \mathrm{kyr}$ B.P. event inferred from $\delta 180$ records of stalagmites from China, Oman, and Brazil. Geology, November de 2009, p. 4. doi: 10.1130/G30126A.1.

CLARKE, M. L.; RENDELL, H. M.; WINTLE, A. G. Quality assurance in luminescence dating. Geomorphology, 29, 1999, p. 173-185.

CORRÊA, A. B. Mapeamento geomorfológico de detalhe do maciço da Serra da Baixa Verde, Pernambuco: estudo da relação entre a compartimentação geomorfológica e a distribuição dos sistemas geoambientais. Dissertação de Mestrado, 183. Recife: Universidade Federal de Pernambuco, 1997.

CORRÊA, A. B. Antropogenese e Morfogênese sob a ação de eventos climáticos de alta magnitude no semiárido pernambucano: O caso da bacia do Riacho Salgado. Revista Brasileira de Geomorfologia, 12, 2011, p. 25-36.

CORRÊA, A. B.; MENDES, I. A. O problema das Superfícies de Erosão: Novas abordagens conceituais e metodológicas. Revista de Geografia (Recife), 18(2), 2002, p. 70-86. 
CORRÊA, A. B.; BARROS, A. M.; ALMEIDA, J. M. Revisitando os Altos Pelados: Desertificação e processos superficiais na bacia do Riacho Grande - PB. Revista de Geografia, 33(4), 2016, p. 335-355. Fonte:

https://periodicos.ufpe.br/revistas/revistageografia/article/view/229292/23649.

CORRÊA, A. B.; TAVARES, B. A.; LIRA, D. R.; MUTZENBERG, D. S.; CAVALCANTI, L. C. The Semi-arid Domain of the Northeast of Brazil. In. SALGADO, A. A.; SANTOS, L. J.; PAISANI, J. C. The Physical Geography of Brazil (p. 119-150). Springer International Publishing, 2019.

CRANDALL, R. Geografia, Geologia, Suprimento d'água, transportes e açudagens. I.F.O.S., Série 1BD (Publicação, 10), 1910.

DANKO, L. V.; BEZRUKOVA, E. B.; ORLOVA, L. A. Reconstructing the development of the geosystems of the Primorsky Range during the latter half of the Holocene. Geography and Natural Resources, 30(3), 2009, p. 246-252. doi:10.1016/j.gnr.2009.09.008.

DEMEK, J. Manual of detailed geomorphological map.ing. Prague: Prague Academie, 1972.

GODFREY-SMITH, D. I.; HUNTLEY, D. J.; CHEN, W. H. Optical dating studies of quartz and feldspar sediment extracts. Quaternary Science Reviews, 7, 1998, p. 373-380. doi:10.1016/0277-3791(88)90032-7.

GRIEVE, S. W.; HALE, T. C.; PARKER, R. N.; MUDD, S. M.; CLUBB, F. J. Controls on Zero-Order Basin Morphology. Journal od Geophysical Research: Earh Science, 123(12), 2018, p. 3269-3291. doi:10.1029/2017JF004453.

HUNTLEY, D. J.; GODFREY-SMITH, D. I.; THEWALT, M. L. Optical Dating of sediments. Nature, 313, 1985, p. 105-107.

HUNTLEY, D. J.; GODFREY-SMITH, D. I.; THEWALT, M. L.; BERGER, G. W. Thermoluminescence spectra of some mineral samples relevant to thermoluminescence dating. Journal of Luminescence, 39(3), 1988, p. 123-136. doi:10.1016/00222313(88)90067-1.

JAMES, P. E. Observations on the Physical Geography of Northeast Brazil. Annals of the Association of American Geographers, 42 (2), 1952, p. 153-176.

KING, L. A Geomorfologia do Brasil Oriental. Revista Brasileira de Geografia, 1956, p. 147-265.

KING, L. The Morphology of the Earth (2 ed.). Edinburg: Oliver and Boyd, 1967.

MONTEIRO, C. A. F. On the "desertification" in northeast Brazil and man's role in this process. Latin American, 9, 1988, p. 1-40. 
OLIVEIRA, M. A.; SANTOS, J. C.; LEMOS, R. 80,000 years of geophysical stratigraphic record at the Serra da Capivara National Park, in northeastern Brazil: Uncovering hidden deposits and landforms at a canyon's floor. Journal of South American Earth Sciences, Pre Proof. 2020. doi:10.1016/j.jsames.2020.102691.

OLLEY, J. M.; CAITCHEON, G. G.; MURRAY, A. The distribution of ap.arent dose as determined by Optically Stimulated Luminescence in small aliquots of fluvial quartz: Implications for dating young sediments. Quaternary Science Reviews, 17(11), 1998, p. 1033-1040. doi:10.1016/S0277-3791(97)00090-5.

PEULVAST, J.; CLAUDINO-SALLES, V. Step.ed surfaces and palaeolandforms in the northern Brazilian Nordestee: constraints on models of morphotectonic evolution.

Geomorphology, 62(1-2), 2004, p. 89-122.

QUEIROZ NETO, J. P. Geomorfologia e Pedologia. Revista Brasileira de Geomorfologia, 1(1), 2000, p. 59-67. doi:10.20502/rbg.v1i1.70.

RENDELL, H. M.; WEBSTER, S. E.; SHEFFER, N. L. Underwater bleaching of signals from sediment grains: new experimental data. Quaternary Science Reviews, 13(5-7), 1994, p. 433-435. doi:10.1016/0277-3791(94)90055-8.

ROBERTS, R.; BIRD, M.; OLLEY, J.; GALBRAITH, R.; LAWSON, E.; LASLETT, G., . . . HUA, Q. Optical and radiocarbon dating at Jinmium rock shelter in northern Australia.

Nature, 393, 1998, p. 358-362. doi:10.1038/30718.

STOKES, S. Luminescence dating ap.lications in geomorphological research.

Geomorphology, 29(1), 1999, p. 153-171. doi:10.1016/S0169-555X(99)00012-4.

THOMAS, M. F. Landscape sensitivity to rapid environmental change - a Quaternary perspective with examples from tropical areas. Catena, 55, 2004, p. 107-124.

WAGNER, G. A. Age Determination of Young Rocks and Artifacts: Physical and Chemical Clocks in Quaternary Geology and Archaeology. New York: Springer, 1998. 